\title{
Food habits of ungulates in dry tropical forests of Gir Lion Sanctuary, Gujarat, India
}

\author{
Jamal A. KHAN*
}

\begin{abstract}
Khan J. A. 1994. Food habits of ungulates in dry tropical forests of Gir Lion Sanctuary, Gujarat, India. Acta theriol. 39: 185-193.

Food habits of chital Axis axis (Exrleben, 1777), sambar Cervus unicolor (Kerr, 1792) and nilgai Boselaphus tragocamelus (Pallas, 1776) of Gir Lion Sanctuary were studied from January 1987 to December 1988. Data were collected on feeding animals by direct observations using scan and focal animal sampling methods. Results suggest that all three species are mixed feeders to varying degree and grass to browse ratio varied significantly in different seasons. Chital utilised 38 species of shrubs, ten species of grasses and two species of climbers whereas sambar and nilgai utilised 29 and 19 species of shrubs, respectively. As a result of drought in 1987, chital utilised far greater proportion of browse (leaves and shoots) during 1988 compared to 1987, sambar diet mainly comprised of bark material of six plant species during winter and summer of 1988. All three species utilised different species of Acacia and Zizyphus in Gir but their utilisation differed significantly between different species thereby facilitating their co-existence.
\end{abstract}

Wildlife Institute of India, P.O. Box - 18, Chandrabani, Dehradun 248 001, India

Key words: Axis axis, Cervus unicolor, Boselaphus tragocamelus, dry deciduous forest, food habits, Gir Lion Sanctuary, India

\section{Introduction}

Food availability is one of the most important factors influencing the distribution of free ranging wild ungulates and hence formulation of management strategy for a protected area necessarily requires adequate information on the food habits of different species (Chamrad and Box 1968, Fitzgerald and Waddington 1979, Holecheck et al. 1982, Gill et al. 1983). Equally important for sound management is the information on spatio-temporal variation in food availability, possibility of competition for certain food resources and hence food regulating the ungulate population. Detailed dietary studies on Indian ungulate species are lacking and very few studies have been conducted so far (e.g. Schaller 1967, Berwick 1974, Sharatchandra and Gadgil 1975, Dinerstein 1979, Green 1985, Chattopadhya and Bhattacharya 1986, Johnsingh and Shankar 1991). These studies have provided accounts of food spectrum and seasonal variation in diet of different species.

* Present \& postal address: Centre of Wildlife \& Ornithology, Aligarh Muslim University, Aligarh 202012 , India 
However, as a whole, studies on food habits in Indian subcontinent have lagged behind in comparison to Africa (see McNaughton and Georgiadis 1986 for a review) and North America (e.g. Drawe 1968, Krausman 1978, John et al. 1980) where extensive research on food habits has resulted in significant advancements in the field of wildlife ecology and management. This paper deals with the food habits of chital Axis axis (Exrleben, 1777), sambar Cervus unicolor (Kerr, 1792) and nilgai Boselaphus tragocamelus (Pallas, 1776). Data were collected in Gir Lion Sanctuary from January 1987 to December 1988 under a research program aimed at formulating conservation strategy for the last wild population of Asiatic lions in Gir.

\section{Study area}

Gir Lion Sanctuary and National Park (hereafter called Gir) in Kathiawar peninsula of Gujarat, covers an area of $1412 \mathrm{~km}^{2}$. The vegetation is tropical dry deciduous interspersed with tropical thorn forest. Nearly $70 \%$ of the total area of Gir is covered with teak Tectona grandis and its several associates. Three management units exist in Gir, i.e. sanctuary west, national park and sanctuary east. These units differ in terms of vegetation, rainfall, topography, human settlement density and hence degradation. The grazing by livestock of Maldhari pastoral community is heaviest in sanctuary west and least in national park. There is a cool dry winter from December to March (average minimum $9^{\circ} \mathrm{C}$ ) followed by a hot dry summer (average maximum $42^{\circ} \mathrm{C}$ ) which lasts until mid June. The monsoon breaks in June and continues till September and is followed by a dry post monsoon season till mid December. Average rainfall over the past 28 years from west and 10 years from east are approximately $1000 \mathrm{~mm}$ and $800 \mathrm{~mm}$ respectively. In 1987, however, sanctuary west and east received only 199 and $456 \mathrm{~mm}$ of rainfall respectively. The low rainfall resulted in severe drought conditions which caused extensive mortality in several plant species and at the same time heavy debarking by sambar was also noticed in Gir (Khan et al. 1990).

\section{Methods}

Direct observations were taken on feeding ungulates on daily basis while conducting regular vehicle and line transect counts. Scan and focal animal sampling methods were used for data collection (Altman 1974). The animals were observed as long as feeding activity continued and the group was in sight. While in scan sampling, the activity of all individuals in a group was recorded at five minutes sampling intervals, a particular individual was selected in a group in focal animal sampling and its activity recorded at the same time intervals. The monthly direct observations were summarized on seasonal basis to calculate the contribution of different plant species as well as browse to grass ratios. The low sample size did not allow calculation of monthly variation in the dietary differences in different sex and age groups of ungulates.

The diet breadth $(B)$ for each ungulate species for each season was calculated by following Negi et al. (1993) using Levins's response breadth $(B)$ formula:

$$
B=\frac{1}{\left(\Sigma p_{i}^{2}\right) s}
$$

where $p_{i}$ is the proportion of plant species $i$, and $s$ is the total number of plant species utilized by an ungulate species. The value of measured $B$ ranges from 0 to 1 with 1 indicating the widest breadth. 
The dietary similarity index (DSI) between any two ungulate species was calculated following Schoener (1970) using the formula:

$$
\text { DSI }=1-1 / 2 \Sigma\left(p_{x i}-p_{y i}\right)
$$

where $p_{x i}\left(p_{y i}\right)$ is the proportion of a plant species $i$ in the diet of ungulate species $x$ and $y$. The DSI values also range from 0 to 1 with 1 indicating maximum similarity.

$\chi^{2}$-test and $t$-test were used to find out differences in grass to browse ratios in various seasons and year following Fowler and Cohen (1986). The nomenclature of plant species follows Patel (1984).

\section{Results}

\section{Chital}

Chital utilised 38 species of trees and shrubs, ten species of grasses and two species of climbers in Gir (Table 1). Chital is a mixed feeder as it utilised grass as well as browse. The grass to browse ratio varied significantly between the seasons $\left(\chi^{2}=18.07, \mathrm{df}=3, p<0.01\right)$. The grass proportion in diet was lowest in winter (55\%) and highest in monsoon (92\%) during 1987 (Fig. 1a). Some of the shrub species utilised in greater proportion than others were Acacia nilotica, Capparis sepiaria, Helicteres isora, Zizyphus mauritiana and Zizyphus nummularia. The monsoon failed to arrive in Gir during 1987 and low rainfall did not bring any significant changes in grass cover. The proportion of browse thereafter increased and dominated in chital diet until next monsoon (Fig. 1b). Chital utilised browse in far greater proportion during 1988 than 1987 however browse intake did not differ significantly between years $(t=1.85, \mathrm{df}=6, p>0.10)$. The grass cover deteriorated to its lowest level and chital supplemented its diet by available fruits. Acacia nilotica, Capparis sepiaria, Helicteres isora and Zizyphus spp. dominated the diet of chital again. The continuous rains in July 1988, brought dramatic changes in ground cover and grasses again constituted the bulk of the chital diet in monsoon and post monsoon seasons. The diet breadth value for chital was highest during winter $(B=0.38)$ and lowest in monsoon $(B=0.15)$ of 1988 . The diet similarity index (DSI) value was lowest between chital and sambar (0.29) and highest between chital and nilgai $(0.40)$ while sambar-nilgai combination had an intermediate value $(0.31)$.

\section{Sambar}

The sambar is also a mixed feeder. However, browse dominated its diet throughout the year (Fig. 1c). Sambar utilised 29 woody species and one species of climber (Table 1). Capparis sepiaria, Emblica officinalis, Helicteres isora, Xeromphis spinosa, Tectona grandis and Wrightia tinctoria mostly dominated sambar diet in various seasons. Sambar utilized bark of several plant species during winter and summer of 1988 and its proportion was significantly higher compared to proportion of leaves and shoots (Fig. 2). Thirteen species of plants were found to have debarking signs however only six species could actually be observed being utilized by sambar. There was no bark utilization during monsoon 
Table 1. Dietary spectrum of chital Axis axis, sambar Cervus unicolor and nilgai Boselaphus tragocamelus in Gir Lion Sanctuary. PE - part eaten, DU - degree of use, L - leaf, S - shoot, F - fruit, P - pods, C - culm, B - bark, X - selected once, XX - selected occasionally, XXX - selected frequently.

\begin{tabular}{|c|c|c|c|c|c|c|}
\hline \multirow{2}{*}{ Plant species eaten } & \multicolumn{2}{|c|}{ Chital } & \multicolumn{2}{|c|}{ Sambar } & \multicolumn{2}{|c|}{ Nilgai } \\
\hline & $\mathrm{PE}$ & $\mathrm{DU}$ & $\mathrm{PE}$ & $\mathrm{DU}$ & $\mathrm{PE}$ & DU \\
\hline 1 & 2 & 3 & 4 & 5 & 6 & 7 \\
\hline \multicolumn{7}{|l|}{ Trees and shrubs } \\
\hline Acacia catechu & $\mathrm{L}+\mathrm{F}$ & $\mathrm{XX}$ & $\mathrm{F}$ & $\mathrm{X}$ & $\mathrm{L}$ & XXX \\
\hline Acacia leucophloea & $\mathrm{L}+\mathrm{S}+\mathrm{P}$ & $\mathrm{XxX}$ & $\mathrm{L}+\mathrm{S}+\mathrm{P}$ & $\mathrm{XXX}$ & $\mathrm{L}+\mathrm{S}+\mathrm{P}$ & $\mathrm{XXX}$ \\
\hline Acacia nilotica & $\mathrm{L}+\mathrm{S}+\mathrm{P}$ & $\mathrm{XXX}$ & $\mathrm{L}+\mathrm{F}$ & $\mathrm{XXX}$ & $\mathrm{L}+\mathrm{S}+\mathrm{P}$ & $\mathrm{XXX}$ \\
\hline Acacia senegal & $\mathrm{F}$ & $\mathrm{X}$ & - & - & - & - \\
\hline Adina cordifolia & - & - & B & $\mathrm{XXX}$ & - & - \\
\hline Aegle marmelos & $\mathrm{L}$ & $\mathrm{X}$ & - & - & - & - \\
\hline Agave ingens & $\mathrm{L}$ & $\mathrm{X}$ & - & - & - & - \\
\hline Albizia procera & $\mathrm{L}$ & $\mathrm{X}$ & - & - & - & - \\
\hline Balanites aegyptica & $\mathrm{L}+\mathrm{F}$ & $\mathrm{XXX}$ & - & - & $\mathrm{L}+\mathrm{S}$ & $\mathrm{XXX}$ \\
\hline Barleria prionitis & $\mathrm{L}$ & $\mathrm{XXX}$ & - & - & - & - \\
\hline Bauhinia racemosa & $\mathrm{L}+\mathrm{F}$ & $\mathrm{XXX}$ & $\mathrm{L}+\mathrm{F}$ & $\mathrm{XXX}$ & $\mathrm{L}+\mathrm{S}$ & $\mathrm{XXX}$ \\
\hline Bombax ceiba & - & - & B & $\mathrm{XXX}$ & - & - \\
\hline Butea monosperma & $\mathrm{L}+\mathrm{S}$ & $\mathrm{X}$ & - & - & $\mathrm{L}+\mathrm{S}$ & $\mathrm{XXX}$ \\
\hline Capparis sepiaria & $\mathrm{L}$ & $\mathrm{XXX}$ & $\mathrm{L}+\mathrm{S}$ & $\mathrm{XXX}$ & $\mathrm{L}$ & $\mathrm{XX}$ \\
\hline Carissa carandas & $\mathrm{L}+\mathrm{S}+\mathrm{F}$ & $\mathrm{XXX}$ & $\mathrm{L}+\mathrm{B}$ & $\mathrm{XXX}$ & $\mathrm{L}+\mathrm{S}$ & $\mathrm{XX}$ \\
\hline Cassia fistula & $\mathrm{F}$ & $\mathrm{XX}$ & B & $\mathrm{XX}$ & - & - \\
\hline Cassia tora & $\mathrm{P}$ & $\mathrm{XX}$ & $\mathrm{L}+\mathrm{P}$ & $\mathrm{X}$ & - & - \\
\hline Dichrostachys cinerea & $\mathrm{L}$ & $\mathrm{XXX}$ & $\mathrm{L}$ & $\mathrm{XXX}$ & $\mathrm{L}$ & $\mathrm{XXX}$ \\
\hline Diospyros melanoxylon & $\mathrm{L}+\mathrm{F}$ & $\mathrm{XXX}$ & $\mathrm{L}$ & $\mathrm{XX}$ & $\mathrm{L}$ & $\mathrm{X}$ \\
\hline Ehretia laevis & $\mathrm{L}$ & $\mathrm{XX}$ & - & - & - & - \\
\hline Embilica officinalis & $\mathrm{L}+\mathrm{F}$ & $\mathrm{XXX}$ & $\mathrm{L}+\mathrm{F}+\mathrm{B}$ & $\mathrm{XXX}$ & $\mathrm{L}+\mathrm{S}$ & $\mathrm{XX}$ \\
\hline Ficus benghalensis & - & - & $\mathrm{L}$ & $\mathrm{X}$ & - & - \\
\hline Ficus religiosa & $\mathrm{L}$ & $\mathrm{X}$ & $\mathrm{L}$ & $\mathrm{X}$ & - & - \\
\hline Flaucortia indica & $\mathrm{L}$ & $\mathrm{XX}$ & - & - & - & - \\
\hline Helicteres isora & $\mathrm{L}$ & $\mathrm{XXX}$ & $\mathrm{L}+\mathrm{S}$ & $\mathrm{XXX}$ & $\mathrm{L}+\mathrm{S}$ & XXX \\
\hline Holoptelea integrifolia & $\mathrm{L}$ & $\mathrm{XX}$ & - & - & - & - \\
\hline Holarrhena antidysenterica & $\mathrm{L}$ & $\mathrm{XX}$ & - & - & - & - \\
\hline Ixora arborea & $\mathrm{L}$ & $\mathrm{X}$ & - & - & - & - \\
\hline Morinda tinctoria & $\mathrm{L}$ & $\mathrm{X}$ & $\mathrm{L}$ & $\mathrm{X}$ & $\mathrm{L}$ & $\mathrm{X}$ \\
\hline Mitragyna parvifolia & - & - & B & $\mathrm{XXX}$ & - & - \\
\hline Sapindus emarginatus & $\mathrm{L}$ & $\mathrm{X}$ & - & - & - & - \\
\hline Securinega leucopyros & $\mathrm{L}$ & $\mathrm{X}$ & - & - & - & - \\
\hline Syzyguim rubicundum & $\mathrm{L}+\mathrm{F}$ & $\mathrm{XX}$ & $\mathrm{L}$ & $\mathrm{X}$ & - & - \\
\hline Tectona grandis & $\mathrm{L}$ & $\mathrm{X}$ & B & $\mathrm{XXX}$ & - & - \\
\hline Terminalia bellirica & $\mathrm{F}$ & $\mathrm{XX}$ & $\mathrm{F}$ & $\mathrm{XX}$ & - & - \\
\hline Terminalia crenulata & $\mathrm{L}$ & $\mathrm{X}$ & B & $\mathrm{XX}$ & $\mathrm{L}$ & $\mathrm{xX}$ \\
\hline Wrightia tinctoria & $\mathrm{L}+\mathrm{F}$ & $\mathrm{XX}$ & B & $\mathrm{XXX}$ & $\mathrm{L}+\mathrm{P}$ & $\mathrm{XXX}$ \\
\hline Xeromphis spinosa & $\mathrm{L}+\mathrm{F}$ & $\mathrm{XXX}$ & $\mathrm{L}+\mathrm{B}$ & $\mathrm{XXX}$ & $\mathrm{L}$ & $\mathrm{XX}$ \\
\hline Xeromphis uliginosa & - & - & B & $\mathrm{XXX}$ & - & - \\
\hline Zizyphus mauritiana & $\mathrm{L}+\mathrm{F}$ & $\mathrm{XXX}$ & $\mathrm{L}$ & $\mathrm{xxX}$ & $\mathrm{L}+\mathrm{F}$ & $\mathrm{XXX}$ \\
\hline Zizyphus nummularia & $\mathrm{L}+\mathrm{F}$ & $\mathrm{XXX}$ & - & - & - & - \\
\hline Zizyphus oenoplia & $\mathrm{L}+\mathrm{F}$ & $\mathrm{XXX}$ & $\mathrm{L}$ & $\mathrm{XXX}$ & $\mathrm{L}+\mathrm{F}$ & $\mathrm{XXX}$ \\
\hline Zizyphus xylopyrus & $\mathrm{L}+\mathrm{F}$ & $\mathrm{XxX}$ & $\mathrm{L}$ & $\mathrm{XxX}$ & $\mathrm{L}+\mathrm{F}$ & $\mathrm{XXX}$ \\
\hline
\end{tabular}


Table 1 - concluded.

\begin{tabular}{lllllll}
\hline \multicolumn{1}{c}{1} & 2 & 3 & 4 & 5 & 6 & 7 \\
\hline Grasses & & & & & & - \\
Apluda mutica & $\mathrm{L}+\mathrm{C}$ & $\mathrm{XXX}$ & - & - & - & - \\
Aristida funiculata & $\mathrm{L}+\mathrm{C}$ & $\mathrm{X}$ & - & - & - & - \\
A. ischaemum & $\mathrm{L}+\mathrm{C}$ & $\mathrm{XXX}$ & - & - & - & - \\
Brachiaria ramosa & $\mathrm{L}+\mathrm{C}$ & $\mathrm{XXX}$ & - & - & - & - \\
Chloris barbata & $\mathrm{L}+\mathrm{C}$ & $\mathrm{XX}$ & - & - & - & - \\
Chloris virgata & $\mathrm{L}+\mathrm{C}$ & $\mathrm{XXX}$ & - & - & - & - \\
Chionachne kaenigii & $\mathrm{L}+\mathrm{C}$ & $\mathrm{XXX}$ & - & - & - & - \\
Digitaria ciliaris & $\mathrm{L}+\mathrm{C}$ & $\mathrm{XXX}$ & - & - & - & - \\
Heteropogon contortus & $\mathrm{L}+\mathrm{C}$ & $\mathrm{XXX}$ & - & - & - & - \\
Themeda quadrivalvis & $\mathrm{L}+\mathrm{C}$ & $\mathrm{XXX}$ & - & - & - \\
Climbers & & & & & - \\
Asparagus racemosa & $\mathrm{L}+\mathrm{S}$ & $\mathrm{XXX}$ & - & - & - \\
Comberatum roxbergii & $\mathrm{L}+\mathrm{S}$ & $\mathrm{XXX}$ & $\mathrm{L}+\mathrm{S}$ & $\mathrm{XXX}$ & - \\
\hline
\end{tabular}
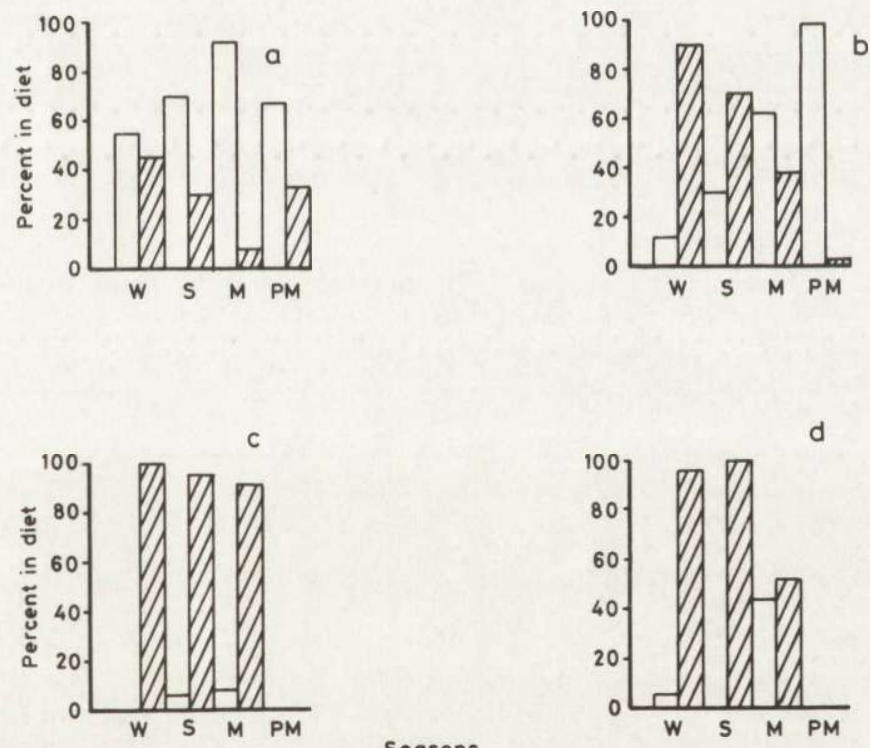

Fig. 1. Variation in grass (open bars) to browse (shaded bars) ratio in winter (W), summer (S), monsoon (M) and post monsoon (PM) seasons for chital (a: 1987, $n=60,48,49$ and 37; b: 1988, $n=$ $202,163,128$ and 43), sambar (c: $1988, n=107,127$ and 13) and nilgai (d: $1988, n=63,59$ and 52) in Gir.

season and thereafter in 1988. The utilization of bark of different species differed significantly during winter $\left(\chi^{2}=52.9, \mathrm{df}=4, p<0.01\right)$ and summer $\left(\chi^{2}=21.9, \mathrm{df}\right.$ $=4, p<0.01$ ). The bark of Wrightia tinctoria, Xeromphis spinosa and Tectona grandis were utilised more compared to other species (Table 2). The diet breadth value for sambar was lowest in winter (0.29) and highest in summer (0.61) of 1988. 


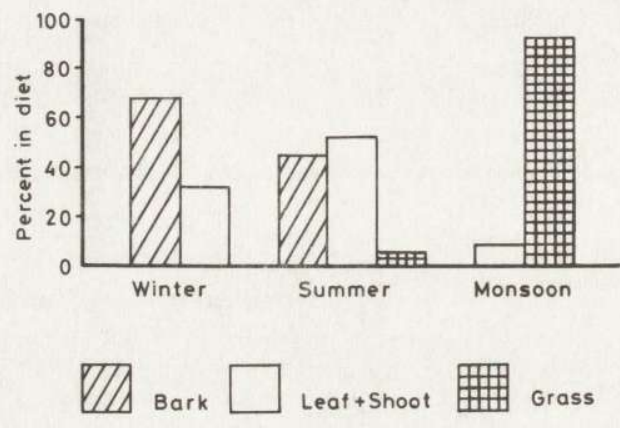

Fig. 2. Percentage of various food components in sambar diet in winter $(n=107)$, summer $(n=127)$ and monsoon seasons $(n=13)$ in Gir.

Table 2. Dietary analysis (plant bark utilization) of sambar in Gir.

\begin{tabular}{|c|c|c|c|}
\hline \multicolumn{2}{|c|}{ Winter $1987-1988(n=73)$} & \multicolumn{2}{|c|}{ Summer $1988(n=55)$} \\
\hline Plant species & $\%$ frequency & Plant species & $\%$ frequency \\
\hline Bombax ceiba & 1.3 & Carissa carandas & 3.6 \\
\hline Mitragyna parvifolia & 1.3 & Mitragyna parvifolia & 9.0 \\
\hline Tectona grandis & 24.6 & Tectona grandis & 25.4 \\
\hline Wrightia tinctoria & 46.5 & Wrightia tinctoria & 40.0 \\
\hline Xeromphis spinosa & 26.0 & Xeromphis spinosa & 21.8 \\
\hline
\end{tabular}

Table 3. Comparison of Acacia - Zizyphus species utilization (\% frequency) during winter 1988 and summer 1988 by chital $(n=202$ and 163), sambar $(n=107$ and 127) and nilgai $(n=63$ and 59).

\begin{tabular}{|c|c|c|c|}
\hline Plant species & Chital & Sambar & Nilgai \\
\hline & Winter 1988 & & \\
\hline Acacia catechu & - & 0.93 & 1.5 \\
\hline Acacia leucophloea & 2.9 & 0.93 & 34.9 \\
\hline Acacia nilotica & 20.7 & - & 4.9 \\
\hline Zizyphus mauritiana & 16.3 & - & 9.5 \\
\hline Zizyphus nummularia & 5.9 & - & - \\
\hline Zizyphus oenoplia & 4.4 & 0.93 & 3.1 \\
\hline Zizyphus xylopyrus & 2.4 & - & 4.7 \\
\hline \multirow[t]{2}{*}{ Other species } & 47.4 & 97.2 & 41.6 \\
\hline & Summer 1988 & & \\
\hline Acacia catechu & - & - & 10.1 \\
\hline Acacia leucophloea & - & - & 27.1 \\
\hline Acacia nilotica & 34.3 & 4.7 & 10.1 \\
\hline Zizyphus mauritiana & 6.7 & 3.9 & 10.1 \\
\hline Zizyphus nummularia & - & - & - \\
\hline Zizyphus oenoplia & 1.2 & - & - \\
\hline Zizyphus xylopyrus & - & - & - \\
\hline Other species & 57.8 & 91.4 & 42.6 \\
\hline
\end{tabular}


Nilgai

The nilgai also utilised grass and browse in varying proportions (Fig. 1d) which varied significantly during different seasons $\left(\chi^{2}=156, \mathrm{df}=3, p<0.01\right)$. Nineteen species of trees and shrubs were recorded to be utilized by nilgai in Gir (Table 1). The nilgai utilized all the plant parts readily such as pods, leaves and twigs. Acacia nilotica, Acacia leucophloea, Butea monosperma and Zizyphus mauritiana dominated its diet. Nilgai switched over to total browse material during summer season. The diet breadth value for nilgai was also lowest in winter $(0.42)$ and highest in summer (0.89) of 1988.

The Acacia and Zizyphus species were utilized by all three ungulate species however there existed a clear difference in their utilization (Table 3). Chital utilized Acacia nilotica and Zizyphus mauritiana in greater proportion whereas nilgai largely subsisted on Acacia leucophloea during winter of 1988. A similar pattern was observed during summer season.

\section{Discussion}

The large flight distance of ungulate populations to the observer and disturbance due to movement of local people made long continuous feeding observations extremely difficult in Gir resulting in low sample sizes of feeding observations. However data, collected under unusual set of ecological conditions in Gir due to drought, are of immense value to understand the response of ungulate community to such altered habitat conditions by comparing it with other protected areas.

Chital is reported to be primarily a grazer in other protected areas as grass dominated its diet during most of the seasons and the proportion of browse was reduced to traces during monsoon (Schaller 1967, Berwick 1974, Sharatchandra and Gadgil 1975, Dinerstein 1979, Johnsingh and Shankar 1991). The main factors identified affecting the diet selection in these areas were phenological, food availability and its nutritional status and the annual burning regime of grasses. Grasses grew in these areas after the rains in May and June creating optimum foraging conditions for chital during monsoon and became dormant during winter after seeding. Chital supplemented their diet after this period with browse material till the grazing conditions once again improved with the burning of grasses during late winter. The grasses follow the same growth pattern in Gir except that late fires in March do not result in fresh grass growth due to lack of moisture. The observed dietary pattern during 1987 was similar to other areas as grasses formed bulk of chital diet during monsoon and post monsoon season in Gir. However, chital supplemented their diet with browse (mainly fruits) in winter. The increase in browse proportion coincided with peak fruiting in plants and fawning season of chital in Gir. It seems that lactating females utilized the fruits mainly because of their higher nutritional demand. The observations suggested increase in grass consumption during summer at a time when grasses were dry 
and low in protein contents. A short scarcity period of browse material during the peak leaf fall and peak rutting season of chital appeared to be responsible for higher grass consumption. It seems that chital subsisted on low quality diet during summer and spent more time and energy on rutting activities rather than investing it in locating scarce high quality browse material. The failure of monsoon in 1987 and an influx of approximately 0.2 million outside cattle during early winter in 1987 left whole of Gir overgrazed. The large chital population responded to such conditions by switching over to browse material in winter and summer of 1988. A comparison between average diet breadth values for winter and summer of $1987(0.21)$ and $1988(0.30)$ showed a significant increase $(p<$ 0.05 ) suggesting a decrease in selectivity of diet mainly due to low food availability and its poor quality.

Sambar is a browser as the available literature suggests (Schaller 1967, Berwick 1974) and the grasses comprised only a fraction of its diet mainly during monsoon. The sambar utilised bark of several plant species during winter of 1988 and bark remained a major food source until the monsoon after which there was no more bark utilization. There have been past records of sambar feeding on bark of different plant species (e.g. Schaller 1967). However no such incident was recorded prior to the 1987 drought in Gir (e.g. Berwick 1974). It has been suggested that sympatric ungulate species maintain a resource partitioning mechanism among themselves to avoid competition for a common food resource and facilitate their co-existence by utilizing different food components (Schoener 1974, Green 1985, McNaughton and Georgiadis 1986). As chital population utilised more and more browse during winter, sambar utilised bark to avoid the competition for its food resources (leaves and shoots) with chital and nilgai.

The nilgai also exhibited a mixed feeding pattern and browse dominated its diet throughout the year. The nilgai can subsist on low quality food and survive in sub-optimal habitats due to its large body size and low energy requirements per unit body surface area. The average diet breadth value was highest for nilgai (0.70) compared to sambar $(0.49)$ and chital $(0.25)$ which was in accordance with its body size.

Acknowledgement: I would like to thank Mr H. S. Panwar, director, Wildlife Institute of India, for providing me financial support to carry out this work. I am greatly indebted to Drs W. A. Rodgers, A. J. T. Johnsingh, A. H. Musavi, P. K. Mathur and R. Chellam for their help during the study. Rashid, Salim, Afif and Ashfaque are thanked for their help in manuscript preparation.

\section{References}

Altman J. 1974. Observational study of behaviour: Sampling methods. Behaviour 49: 227-265.

Berwick S. H. 1974. The community of wild ruminants in Gir forest. Ph. D. thesis, Yale University, USA: $1-226$.

Chamrad A. D. and Box T. W. 1968. Food habits of white tailed deer in South Texas. J. Range Manage. 21: 158-164. 
Chattopadhyay B. and Bhattacharya T. 1986. Food habits of blackbuck Antelope cervicapra L. of Ballarpur Wildlife Sanctuary, West Bangal, India. Trop. Ecol. 27: 93-100.

Dinerstein E. 1979. An ecological survey of Royal Karnali Bardia Wildlife Reserve. Part II: Habitat/ Animal interaction. Biol. Conserv. 16: 265-300.

Drawe D. L. 1968. Mid summer diet of deer on the Welder Wildlife Refuge. J. Range Manage. 21: $164-166$.

Fitzgerald A. E. and Waddington D. C. 1979. Comparison of two methods of faecal analysis of herbivore diet. J. Wildl. Manage. 43: 468-473.

Fowler J. and Cohen L. 1986. Statistics for Ornithologist. BTO Guide No 22, British Trust for Ornithology, Hertfordshire: 1-175.

Gill R. B., Carpenter L. H., Bartmann R. M., Baker D. L. and Schoonveld G. G. 1983. Faecal analysis to estimate mule deer diets. J. Wildl. Manage. 47: 902-915.

Green M. J. B. 1985. Aspects of the ecology of the Himalayan musk deer. Ph. D. thesis, University of Cambridge, Cambridge: 1-280.

Holecheck J. L., Vavra M. and Piper R. D. 1982. Botanical composition determination of range herbivore diets : A review. J. Range Manage. 35: 309-315.

Johnsingh A. J. T. and Shankar K. 1991. Food plants of chital, sambar and cattle on Mundanthurai Plateau, Tamil Nadu, South India. Mammalia 55: 57-66.

John G. K., Drave L. and Scott G. 1980. Changes in the diet and nutrition with increased herd size in Texas white-tailed deer. J. Range Manage. 33: 28-34.

Khan J. A., Rodgers W. A., Johnsingh A. J. T. and Mathur P. K. 1990. Gir lion project: ungulate habitat ecology in Gir. Project report, Wildlife Institute of India, Dehradun: 1-214.

Krausmann P. R. 1978. Forage relationships between two deer species in Big Bend National Park, Texas. J. Wildl. Manage. 42: 101-107.

McNaughton S. J. and Georgiadis N. J. 1986. Ecology of African grazing and browsing mammals. Ann. Rev. Ecol. Syst. 17: 39-65

Negi G. C. S., Rikhari H. C., Ram J. and Singh S. P. 1993. Foraging niche characteristics of horses, sheep and goats in an alpine meadow of the Indian Central Himalaya. J. Appl. Ecol. 30: 383-394.

Patel R. I. 1984. Forest flora of Gujarat State. Forest Department, Gujarat State, Baroda: 1-397.

Schaller G. B. 1967. The deer and the tiger. Univ. Chicago Press, Chicago: 1-370.

Schoener T. W. 1970. Non-synchronous spatial overlap of lizards in patchy habitats. Ecology 51: 408-418.

Schoener T. W. 1974. Resource partitioning in ecological communities. Science 185: 27-39.

Sharatchandra H. C. and Gadgil M. 1975. A year in Bandipur. J. Bombay Nat. Hist. Soc. 72: 623-647.

Received 27 October 1993, accepted 7 March 1994. 